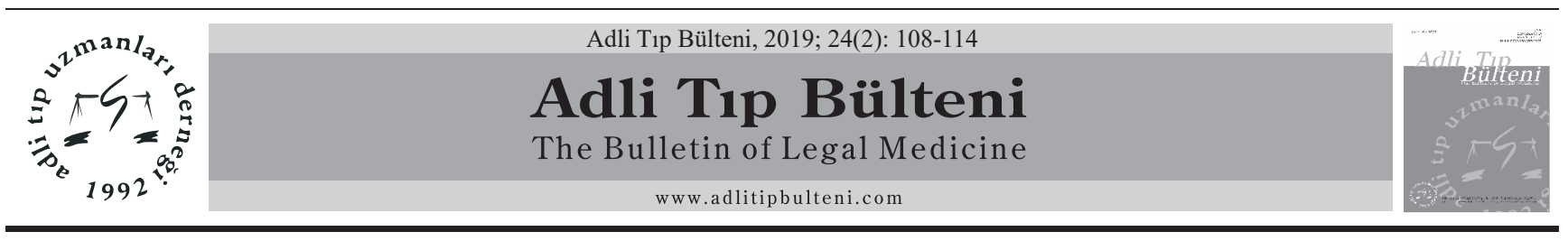

ARAȘTIRMA / RESEARCH ARTICLE

\title{
Ekstremite Kırığı Olgularında Tedavi Seçeneklerinin ve Meslekte Çalışma Gücü Kaybı Oranı ve Özürlülük Oranlarının Karşılaştırılması
}

\section{Comparison of Treatment Options and Loss of Labor and Disability Ratio in Patients with Extremity Fractures}

\author{
Ender Şenol, Cemil Çelik*, Uğur Ata, Orhan Meral, Nadir Özkayın
}

\begin{abstract}
$\ddot{\mathbf{O} z}$
Amaç: Çalışmamızda; trafik kazası sonucu meydana gelen kemik kırıklarına uygulanan tedavilerin başarıları ile bu tedavi sonucunda kalan sekellere ait meslekte kazanma gücü kaybı ve özürlülük oranlarının hesaplanarak kıyaslanması amaçlanmıştır.

Gereç ve Yöntem: 01 Şubat 2016 - 01 Şubat 2017 tarihleri arasında travma sonucu Ege Üniversitesi Tıp Fakültesi Ortopedi ve Travmatoloji Anabilim Dalında tedavi uygulanmış ve Ege Üniversitesi Tıp Fakültesi Adli Tıp Anabilim Dalımıza sekel oranının hesaplanması için başvuru yapılması istenmiş tek taraflı ekstremite kırı̆̆ı olan 142 olgu değerlendirildi.

Bulgular: En sık kırık saptanan ilk üç kemik olan tibia, femur, tibia+fibula kırıklarının anlamlı olarak motosiklet kazalarında daha fazla gözlendiği saptandı. Alçı-atel tedavisi ile plak vida ve intramedüller çivi tedavileri arasında sekel oranları yönünden anlamlı fark olduğu saptanmıştır $(\mathrm{p}<0.05)$. Kırıkların ekstremitede bıraktığı sekeller üzerinden hesaplanan maluliyet ve özürlülük oranları değerlendirildiğinde; özürlülük ve meslekte kazanma gücü kaybı oranları arasında pozitif yönde güçlü korelasyon olduğu, meslekte kazanma gücü kaybı oranının ortalama $\% 15$, özürlülük oranının ise ortalama $\% 5,5$ olarak hesaplandığı ve her ikisi arasında saptanan bu farkın istatistiksel olarak anlamlı bir fark olduğu sonucuna ulaşıldı.

Sonuç: Motosiklet kullanan genç erkek popülasyonuna yönelik eğitimlerin arttırılması ve özellikle kask ve diğer koruyucu kıyafetlerin yanında alt ekstremiteye yönelik olarak kullanılan koruyucu kıyafetlerin özendirilmesi ve yasal olarak desteklenmesi gerektiği, tazminat için meslekte kazanma gücü kaybı oranı yerine özürlülük oranının kullanılması ve bu oran hesaplanırken meslek ve yaş değerlendirilmesinin yapılmaması nedeniyle mevcut oranların düşmesi ve hak kayıplarına neden olması sebebiyle buna yönelik mağduriyetin ortadan kaldırılması için daha objektif değerlendirmeleri içeren, yaş ile mesleğin de hesaba katıldığı ayrı bir yönetmelik oluşturmaya yönelik adımlar atılması gerektiği kanaatindeyiz.
\end{abstract}

Anahtar Kelimeler: Trafik Kazası, Sekel, Ekstremite Kırığı, Engellilik, Tazminat.

\section{Abstract}

Objective: In our study, the success of the treatments applied to the bone fractures resulting from traffic accidents and the disability reports of those cases prepared using "The Scales of Measurement of Disabilities" and "The Scale of Disability Rates", and the ratios obtained using both scales were compared.

Materials and Methods: In our study we evaluated 142 patients with unilateral extremity fractures who were treated at Ege University Faculty of Medicine, Department of Orthopedics and Traumatology between February 01, 2016 and February 01, 2017 and who applied to our department for the evaluation of the sequelae rate.

Results: There were significant differences in the sequelae rates after orthopedic plastersplint, plate-screw and intramedullary needle treatments $(\mathrm{p}<0.05)$. It was concluded that there was a strong positive correlation between disability and invalidity rates as a result of fractures, the average invalidity rate was calculated as $15 \%$, the disability rate was calculated as $5.5 \%$, and the difference was found to be statistically significant.

Discussion: On compensation account, using "The Scales of Measurement of Disabilities" instead of "The Scale of Disability Rates" due to the lack of professional and age assessment when calculating this ratio, the loss of rights arises. We believe that steps should be taken to create a new regulation that includes age and profession, which includes more objective evaluations for the elimination of this grievance and the calculation of the disability rate.

Keywords: Traffic Accident, Sequelae, Extremity Fracture, Disability, Compensation.

\section{DOI: $10.17986 /$ blm.2019252289}

Ender Şenol: Dr. Öğr. Üyesi, Ege Üniversitesi Tıp Fakültesi Adli Tıp Anabilim Dalı, İzmir Eposta: eeesenol@yahoo.com ORCID iD: https://orcid.org/0000-0002-5057-4526

Cemil Çelik: Arş. Gör. Dr., Ege Üniversitesi Tıp Fakültesi Adli Tıp Anabilim Dalı, İzmir Eposta: cemilcelik89@hotmail.com ORCID iD: https://orcid.org/0000-0002-8103$459 \mathrm{X}$

Uğur Ata: Arş. Gör. Dr., Ege Üniversitesi Tip Fakültesi Adli Tıp Anabilim Dalı, İzmir Eposta: dr.ata52@hotmail.com ORCID iD: https://orcid.org/0000-0002-8400293X

Orhan Meral: Sağlık Bilimleri Üniversitesi İzmir Bozyaka Eğitim ve Araştırma Hastanesi Adli Tıp Birimi, İzmir

Eposta: orhanmeral@ymail.com

ORCID iD: https://orcid.org/0000-0002-7159-1595

Nadir Özkayın: Prof. Dr., Ege Üniversitesi Tıp Fakültesi Hastanesi Ortopedi ve Travmatoloji Anabilim Dalı, İzmir

Eposta: nadiozkayin@gmail.com ORCID iD: https://orcid.org/0000-0001-8767-6238

\section{Bildirimler/ Acknowledgement:}

Yazarlar bu makale ile ilgili herhangi bir çıkar çatışması bildirmemişlerdir.

The authors declare that they have no conflict of interests regarding content of this article.

Yazarlar bu makale ile ilgili herhangi bir finansal destek bildirmemişlerdir.

The Authors report no financial support regarding content of this article.

Geliş: 12.03 .2019

Düzeltme: 30.04 .2019

Kabul: 09.05.2019

p-ISSN: $1300-865 \mathrm{X}$

e-ISSN: 2149-4533 


\section{Giriş}

Kaza sonucu yaralanma ve bu yaralanmanın sonucunda meydana gelen sakatlıklar ülkemizde ve dünyada sık görülen adli olaylardan biridir. Özellikle trafik kazaları her yıl sayıları giderek artan kalıcı sakatlıklara ve dolayısıyla ciddi iş gücü kaybına neden olmaktadır. Türkiye istatistik verilerine göre Türkiye'de 182 bin 669 adet ölümlü yaralanmalı trafik kazası meydana geldiği bildirilmiştir. Ülkemiz karayolu ağında 2017 yılında toplam 1 milyon 202 bin 716 adet trafik kazası meydana geldi. Bu kazaların 1 milyon 20 bin 47 adedi maddi hasarlı, 182 bin 669 adedi ise ölümlü yaralanmalı trafik kazasıdır (1).

Trafik kazalarında özellikle araç dışı trafik kazaları sonucu yayaların maruz kaldığı yaralanmalarda, birincil olarak alt ekstremite kırıklarına sık rastlanmaktadır. Ayrıca kazanın ikincil etkisiyle kafatası, üst ekstremite ve pelvis kırıkları yine s1k rastlanan yaralanma bölgeleridir. Araç içi trafik kazalarında ise özellikle emniyet kemeri önlemi olmayan sürücülerde de ayak ve alt ekstremite kırıkları ile pelvis çıkık ve kırıklarına sık rastlanmakla birlikte üst ektremite kırıklarına daha az rastlanabilmektedir (2).

Kömürcü ve arkadaşlarının yaptığı bir çalışmada ise; Aksaray ilinde meydana gelen motosiklet kazalarına bağ11 kas iskelet yaralanmalarının değerlendirilmesi sonucunda, en sık kırılan kemiğin femur cisim kırığı olduğu, bunu proksimal tibia kırığı, el-el bileği kırıkları, distal femur kırığı, humerus kırığının izlediği, çıkıkların değerlendirilmesi sonucunda da en sık omuz çıkığ 1 meydana geldiği, bunu kalça, falanks ve tibia-talar eklem çıkıklarının izlediği bildirilmiştir (3).

Travma nedeniyle meydana gelen kırıklarda tedavi seçeneklerine baktığımızda; özellikle tibia kırı̆̆ı gibi travmalarda en sık kırılan kemiklerde uygulanan tedaviler arasında konservatif ve cerrahi tedavi seçeneklerinin olduğu bilinmektedir. Konservatif tedaviler içinde en sık uygulanan yöntemlerden biri olan alçı atel uygulamasında yakın doktor takibinin çok önemli olduğunu rapor eden yayınlar vardır. Cerrahi seçenekler arasında yer alan plak-vida uygulamalarında ise hasta seçiminin önemli olduğu bildirilmektedir. Diğer bir cerrahi seçenek olan ve konservatif tedaviye rakip olabilecek intramedüller çivi yönteminde ise iyileşmenin kısa zamanda olmasının önemli bir avantaj olduğunu bildiren yayınlar bulunmaktadır (4).

Diğer sık kırılan kemik kırıklarının tedavi seçeneklerinin karşılaştırıldığı çalışmalarda da; humerus kırıklarında özellikle komplike ve eklemi içeren kırıklar ile açık kırıklarda cerrahi tedavi uygulandığı, ön kol kırıklarında deplase kırıklar haricindeki olgularda konservatif tedavi tercih edildiği, el ve el bileği kırıklarında öncelikle yine konservatif tedavi tercih edildiği ve bu tedavilerin oldukça başarılı olduğu ancak bazı kırık tiplerinde plak-vida uygulamasının tercih edildiği, femur boynu ve kalça ile ilişkili kırıklarında ise konservatif tedavinin yeri olmadığı ve daha çok cerrahi yöntemler tercih edildiğini görmekteyiz (5-8).

Bilindiği gibi, vücutta meydana gelen kırık sonrası konservatif veya cerrahi tedavi yaklaşımlarının kişide oluşacak sekeller üzerine etkisi büyüktür. Klinik olarak bakıldığında bir kemikte meydana gelen kırığga olgunun özeliklerine göre farklı tedavi protokolleri uygulanmaktadır. Tedavide amaç, kırığın anatomik redüksiyonda iyileşmesini sağlamak ve en kısa sürede fonksiyonlarını yapar hale getirmektir (9). Vücutta meydana gelen kırık sonrası oluşan sekel kişinin hayatını idame ettirmede önemli olmakla birlikte adli tıbbi yönüyle değerlendirildiğinde bu sekel vücut fonksiyonlarını etkileyerek cezai ve hukuki sonuçlara yol açmaktadır.

Kalıcı olarak iyileşen kırığın vücutta bıraktığı sekel kişilerin yaşamını idame ettirme yönünden, sekel oranı ise mağduriyetlerinin azaltılması ve tazminat yönünden önemlidir. Ülkemizde meslekte kazanma gücü kaybına yönelik değerlendirme ve raporlama işlemleri Adli Tıp Kurumu, Adli Tıp Uzmanları ya da mahkemelerce belirlenen bilirkişiler tarafindan düzenlenmektedir (10). Özellikle trafik kazaları başta olmak üzere kasten yaralamadan taksirli yaralamalara ya da ölümlere kadar tüm adli olaylarda ceza davasının hemen ardından açılan tazminat davalarında hukuk mahkemelerinin isteği üzerine, İstanbul Adli Tıp Kurumu 3. İhtisas Kurulu başta olmak üzere üniversitelere bağlı adli tıp anabilim dallarında "maluliyet" raporu olarak da bilinen raporlar düzenlenmektedir. Ancak 14.05.2015 tarihli ve 29355 sayılı Resmî Gazetede yayınlanan Karayolları Motorlu Araçlar Zorunlu Mali Sorumluluk Sigortası Genel Şartlarında “01.06.2015 tarihinden itibaren trafik kazası nedeniyle mağdurun tedavisinin tamamlanması sonrasında yetkili bir hastaneden alınacak özürlü sağlık kurulu raporu ile sürekli sakatlık oranının belirlenmesi..." kararı alınmıştır. Ayrıca 20.02.2019 tarihli ve 30692 sayılı Resmi Gazetede yayınlanan "Erişkinler İçin Engellilik Değerlendirmesi Hakkında Yönetmelikte" ise "İş kazası ve/veya meslek hastalığ 1 dışındaki terör/kaza/yaralanma nedeni ile meydana gelen fonksiyon kayıplarında Ek-4'te yer alan Erişkinler İçin Terör, Kaza ve Yaralanmaya Bağlı Durum Bildirir Sağlık Kurulu Raporu düzenlenir" ifadelerinin yer alması nedeniyle söz konusu tarihten itibaren trafik kazası nedeniyle yapılan tazminat ile ilgili değerlendirmeler, adı geçen yönetmelikte belirtilen kurul tarafindan verilecektir.

Çalışmamızda; trafik kazası sonucu meydana gelen kemik kırıklarına uygulanan tedavilerin başarıları ile 
bu tedavi sonucunda kalan sekellerin ve bu sekellere ait oranların "Çalışma Gücü ve Meslekte Kazanma Gücü Kaybı Oranı Tespit İşlemleri Yönetmeliği” ve “Özürlülük Ölçütü, Sınıflandırması ve Özürlülere Verilecek Sağlık Kurulu Raporları Hakkındaki Yönetmelik" ekinde bulunan Özür Oranları Cetveli kullanılarak hesaplanması ve kıyaslanması amaçlanmıştır.

\section{Gereç ve Yöntem}

Çalışmamıza, 01 Şubat 2016 - 01 Şubat 2017 tarihleri arasında travma sonucu Ege Üniversitesi Tıp Fakültesi Ortopedi ve Travmatoloji Anabilim Dalında tedavi uygulanmış ve Ege Üniversitesi Tıp Fakültesi Adli Tıp Anabilim Dalımıza sekel oranının hesaplanması için başvuru yapılması istenmiş 350 olgudan tek taraflı ekstremite kırığı olan 142 olgu değerlendirmeye alınmıştır. Ancak 142 olgunun 21'inde hem üst ekstremitede hem de alt ekstremitede tek taraflı kırık mevcut olduğundan, her kırığın ayrı ayrı değerlendirilebilmesi için 163 tane veri kayıt formu düzenlenmiştir.

Değerlendirmede 142 olgu için hazırlanan olgu rapor formlarına, olguların demografik verileri, olay türü, yaş, kırılan kemik, ameliyat olup olmadığı, ameliyat olmuşsa ameliyat tipi, ameliyat olmuşsa ameliyatın kaç gün sonra yapıldığı, olay tarihi ile muayene tarihi arasındaki süre, sekeller ve kırıklara yapılan tedaviler ayrı ayrı kaydedilmiştir. Ayrıca olgularda meydana gelen kırıklar ve bıraktığı sekel oranları; "Çalışma Gücü ve Meslekte Kazanma Gücü Kaybı Oranı Tespit İşlemleri Yönetmeliği” ve "Özürlülük Ölçütü, Sınıflandırması ve Özürlülere Verilecek Sağlık Kurulu Raporları Hakkındaki Yönetmelik" ekinde bulunan Özür Oranları Cetveli kullanılarak hesaplanmıştır.

Elde edilen veriler IBM SPSS Statistics 25.0" programında \%95 güven aralığında değerlendirilmiştir. Değerlendirmede, frekans analizleri, parametrik ve nonparametrik ki-kare testlerinin yanı sira korelasyon analizleri kullanılmıştır. Karşılaştırma için kullanılan ki-kare testlerinde analiz sonucu elde edilen "p" değeri 0.05 den küçük ise anlamlı fark olarak kabul edilmiştir.

\section{Bulgular}

Çalışma kapsamına alınan olguların dosyaları incelendiğinde; tek taraflı ekstremite kırığı olan 142 olgunun 111 'i erkek (\%78.2), 31 'i (\%21.8) kadın ve yaş ortalamalar1 37.48, standart sapmas1 0.404 olarak saptand1.

Çalışmamızda olguların \%43,7 (62) ile en sık motosiklet kazası, \%29,6 (42) ile araç dışı trafik kazası, \%24,6 (35) ile araç içi trafik kazası ve \%2,1 (3) ile düşme sonucu yaralandığı saptandı.
Travma türü ile yaş ve cinsiyet arasında ilişki olup olmadığ1 incelendiğinde; motosiklet kazası sonucu yaralanan olguların yaş ortalamalarıyla $(32,68)$, araç içi trafik kazası sonucu yaralananların yaş ortalamaları $(44,23)$ arasında istatistiksel olarak anlamlı fark saptan$\mathrm{d}_{1}(\mathrm{p}<0,05)$.

Ayrıca motosiklet kazası sonucu yaralanan olgularımızda erkek sıklığının yine anlamlı olarak daha fazla olduğu saptandı $(\mathrm{p}<0.05)$. Diğer travma türleri karşılaştırmalarında anlamlı bir istatistiksel veri elde edilemedi (Grafik1).

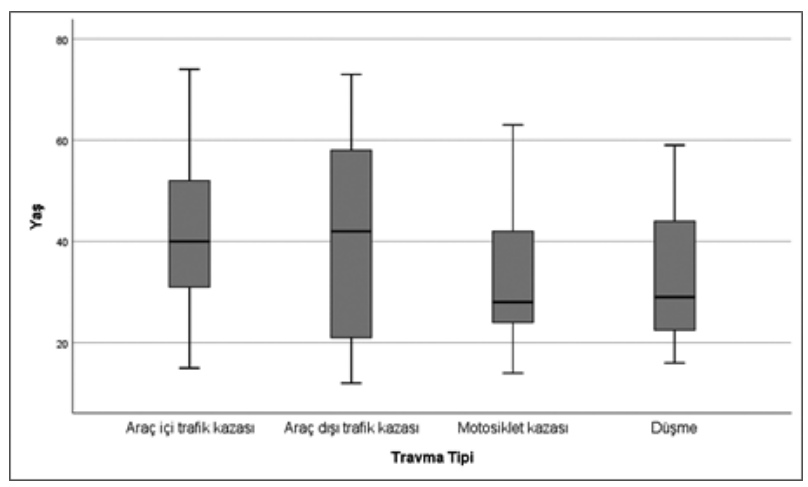

Grafik 1. Travma türleri ve yaş ortalamaları karşılaştırılmasını gösteren boxplot grafiği.

Olgularda meydana gelen kırıkların hangi kemikte olduğu incelendiğinde; \%19,6 (32) oranında en s1k tibia kemiğinde, \%17,2 (28) oranında femurda, \%16 (26) oranında tibia+fibula kemiğinde kırık olduğu saptand1.

Travma tipi ile en sık üç kırık (tibia, femur, tibia+fibula) arasında ilişki olup olmadığı incelendiğinde (Tablo 1); en sık kırık saptanan ilk üç kemik olan tibia, femur, tibia+fibula kırıklarının anlamlı olarak motosiklet kazalarında daha fazla gözlendiği saptandı $(\mathrm{p}<0.05)$.

Travma bölgeleri incelendiğinde ise tek taraflı ekstremite kırıklarının 111 tanesinin (\%68.1) alt ekstremitede meydana geldiği, kalan 52 tanesinin (\%31.9) üst ekstremitede olduğu görülmüştür. Üst veya alt ekstremitede tek taraflı kırık olan 163 verinin; \%69,9 (114) oranındaki k1rığa ameliyat uygulandığı, \%29,4 (48) oranındaki kırığa ameliyat yapılmadığ 1 tespit edildi. 1 tane verinin ameliyat olup olmadığı bilgisine ulaşılamamıştır. Kırıklara olay tarihinden itibaren ortalama 28,66 gün sonra ameliyat yapıldığg tespit edilmiştir.

Kırıklara uygulanan tedavi tipleri incelendiğinde; en sık olarak \%30,7 (50) oranındaki kırığga plak-vida ameliyatı uygulandığı, \%21,5 (35)'ine alçı-atel, \%15,3 (25)'ine intramedüller çivi tedavisi uygulandığı saptandı (Tablo 2). 
Tablo 1. Ekstremitede tek taraflı kırılan kemiklerin dağılımı

\begin{tabular}{|l|c|c|}
\hline Kırılan Kemik & Sıklı̆̆ (n)* & Yüzdesi (\%) \\
\hline Tibia & 32 & 19.6 \\
\hline Femur & 28 & 17.2 \\
\hline Tibia ve Fibula & 26 & 16 \\
\hline Humerus & 18 & 11 \\
\hline Radius & 12 & 7.4 \\
\hline Klavikula & 7 & 4.3 \\
\hline Femur ve Tibia & 7 & 4.3 \\
\hline Karpal kemikler & 6 & 3.7 \\
\hline Radius ve Ulna & 6 & 3.7 \\
\hline Fibula & 4 & 2.5 \\
\hline Pelvis ve Femur & 4 & 2.5 \\
\hline Tarsal kemikler & 3 & 1.8 \\
\hline Patella & 3 & 1.8 \\
\hline Pelvis kemiği & 2 & 1.2 \\
\hline Klavikula ve Humerus & 2 & 1.2 \\
\hline Ulna & 1 & 0.6 \\
\hline Tibia ve Tarsal kemikler & 1 & 0.6 \\
\hline Radius, Ulna ve Klavikula & 1 & 0.6 \\
\hline Total & 163 & 100 \\
\hline (n:vei & & \\
\hline
\end{tabular}

*(n: veri sayıs1)

Olgularda meydana gelen sekellerin kalıcı olarak değerlendirildiği de dikkate alınarak, olay tarihinden itibaren ortalama olarak 37,98 ay sonra muayene edildiği tespit edilmiştir. Olay sonrası olgularda, yapılan tedavi sonrasındaki kalıcı sekeller değerlendirildiğinde; 163 adet tedavi uygulanmış kırıktan 39 (\%23.9) adedinin normal olarak iyileştiği, en sık sekel sıklı̆̆ının da 21 (\%12.9) adet ile ayak bileği hareket kısıtlllığı, 17 (\%10.4) ile diz hareket kisitll1ı̆̆ 1 , 15 (\%9.2) ile ekstremite atrofisi, 12 (\%7.4) ekstremite de açılanma, 11 (\%6.7) ile omuz eklem hareket kısıtll1lı̆gı olduğu görülmüştür.

En sık saptanan (110 adet) üç tedavi tipi (plak-vida, alçı-atel, intramedüller çivi) ile meslekte kazanma gücü
Tablo 2. Kırıklara uygulanan tedavi yöntemlerinin dağılımı.

\begin{tabular}{|l|c|c|}
\hline Tedavi Yöntemi & Sıklı̆̆ (n) & Yüzdesi (\%) \\
\hline Plak-vida & 50 & 30.7 \\
\hline Alçı-atel & 35 & 21.5 \\
\hline İntramedüller çivi & 25 & 15.3 \\
\hline Diğer & 11 & 6.7 \\
\hline K teli & 9 & 5.5 \\
\hline Vida & 7 & 4.3 \\
\hline Kalça protezi & 4 & 2.5 \\
\hline K teli ve vida & 3 & 1.8 \\
\hline $\begin{array}{l}\text { Plak-vida ve intramedüller } \\
\text { çivi }\end{array}$ & 2 & 1.2 \\
\hline Plak-vida ve K teli & 2 & 1.2 \\
\hline Eksternal fiksatör & 1 & 0.6 \\
\hline Bilinmiyor & 14 & 8.6 \\
\hline Total & 163 & 100 \\
\hline
\end{tabular}

kaybı oranı ve özürlülük oranları arasında ilişki olup olmadığı değerlendirildiğinde; alçı-atel tedavisi ile plak vida ve intramedüller çivi tedavileri arasında sekel oranları yönünden anlamlı fark olduğu saptanmıştır $(\mathrm{p}<0.05)$. Ancak aynı anlamlı farkın intramedüller çivi ve plakvida tedavisi arasında olmadığı tespit edilmiştir( $(\mathrm{p}>0.05)$. $\mathrm{Bu}$ sonuçlara göre intramedüller çivi veya plak-vida ameliyatı olanların alçı-atel tedavisi uygulananlara göre özürlülük ve meslekte kazanma gücü kaybı oranlarının anlamlı olarak yüksek olduğu sonucuna varılmıştır (Tablo 3,4$)$.

Çalışmamızda en sık kırık saptanan dört kemiğe (tibia, femur, tibia ve fibula, humerus) baktığımızda; en sık uygulanmış tedavi yöntemlerine göre meslekte kazanma gücü kaybı ve özürlülük oranlarının ortalamaları incelendiğinde meslekte kazanma gücü kaybı oranları ve özürlülük oranları arasında meslekte kazanma gücü kaybı oranı lehine farklar olduğu dikkati çekmiştir (Tablo 5).

Tablo 3. Tedavi yöntemlerine göre meslekte kazanma gücü kaybı oranı dağılımı

\begin{tabular}{|l|c|c|c|c|c|c|}
\hline Tedavi yöntemi & Sıklık (n) & MKGK* Oranı Ortalaması (\%) & S. Deviasyon & S. Sapma & Alt Sınır & Üst Sınır \\
\hline Plak-vida & 50 & 18.39 & 13.42 & 1.89 & 14.58 & 22.2 \\
\hline Alç1-atel & 35 & 9.464 & 8.24 & 1.39 & 6.63 & 12.29 \\
\hline İntramedüller çivi & 25 & 20.75 & 17.42 & 3.48 & 13.56 & 27.94 \\
\hline Total & 110 & 16.09 & 13.80 & 1.31 & 13.48 & 18.69 \\
\hline
\end{tabular}

*Meslekte kazanma gücü kaybı 
Tablo 4. Tedavi yöntemlerine göre özürlülük oranı dağılımı

\begin{tabular}{|l|c|c|c|c|c|c|}
\hline Tedavi yöntemi & Sıklık (n) & Özürlülüik Oranı ortalaması (\%) & S. Deviasyon & S. Sapma & Alt Sınır & Üst sınır \\
\hline Plak-vida & 50 & 5.75 & 4.69 & 0.66 & 4.42 & 7.09 \\
\hline Alçı-atel & 35 & 3.13 & 3.04 & 0.51 & 2.08 & 4.18 \\
\hline İntramedüller çivi & 25 & 8.72 & 10.52 & 2.10 & 4.37 & 13.06 \\
\hline Total & 110 & 5.59 & 6.43 & 1.316 & 4.38 & 6.81 \\
\hline
\end{tabular}

*Meslekte kazanma gücü kaybı

Tablo 5. En sık kırık saptanan dört kemiğe en sık uygulanmış tedavi yöntemlerine göre meslekte kazanma gücü kaybı ve özürlülük oranı tablosu.

\begin{tabular}{|c|c|c|c|}
\hline $\begin{array}{l}\text { Tedavi yöntemi } \\
\text { (en sık) }\end{array}$ & $\begin{array}{l}\text { Sıklık } \\
\text { (n) }\end{array}$ & $\begin{array}{c}\text { Meslekte } \\
\text { kazanma gücü } \\
\text { kaybı oran } \\
\text { ortalaması (\%) }\end{array}$ & $\begin{array}{c}\text { Özürlülülk } \\
\text { oranı } \\
\text { ortalaması } \\
(\%)\end{array}$ \\
\hline \multicolumn{4}{|l|}{ Tibia kırığı } \\
\hline Plak-vida tedavisi & 11 & 17.68 & 5.09 \\
\hline Alç1-atel tedavisi & 9 & 8.4 & 3.2 \\
\hline Vida tedavisi & 4 & 12.25 & 4 \\
\hline $\begin{array}{l}\text { İntramedüller çivi } \\
\text { tedavisi }\end{array}$ & 2 & 31 & 6 \\
\hline \multicolumn{4}{|l|}{ Femur kırığı } \\
\hline $\begin{array}{l}\text { İntramedüller çivi } \\
\text { tedavisi }\end{array}$ & 9 & 10.6 & 7.07 \\
\hline Plak-vida tedavisi & 8 & 25.43 & 11.9 \\
\hline Alçı-atel tedavisi & 2 & 6 & 2.5 \\
\hline \multicolumn{4}{|c|}{ Tibia ve fibula kırığı } \\
\hline Plak-vida tedavisi & 11 & 23.45 & 6.32 \\
\hline $\begin{array}{l}\text { İntremedüller çivi } \\
\text { tedavisi }\end{array}$ & 8 & 23.55 & 8.37 \\
\hline Alç1-atel tedavisi & 2 & 24.73 & 8 \\
\hline \multicolumn{4}{|l|}{ Humerus kırığı } \\
\hline Plak-vida tedavisi & 7 & 15.5 & 3.2 \\
\hline Alç1-atel tedavisi & 3 & 2.3 & 0 \\
\hline $\begin{array}{l}\text { İntremedüller çivi } \\
\text { tedavisi }\end{array}$ & 2 & 9.5 & 2.5 \\
\hline
\end{tabular}

Toplam 163 kırık sonucu ekstremitede kalan sekelin, özürlülük ve meslekte kazanma gücü kaybı oranlarının her ikisi arasında anlamlı bir ilişki olup olmadığı incelendiğinde ise her ikisinin arasında pozitif yönde güçlü korelasyon saptanmıştır. Kırık sonrası ekstremitede kalan sekel üzerinden hesaplanan meslekte kazanma gücü kayb1 ve özürlülük oranları değerlendirildiğinde; kırık sonrası kalan sekellerin meslekte kazanma gücü kaybı oranının ortalaması $\% 15$, özürlülük oranının ise ortalama $\% 5,5$ olarak hesaplandığı ve her ikisi arasında saptanan bu farkın istatistiksel olarak anlamlı bir fark olduğu sonucuna ulaşıldı (Grafik 2).

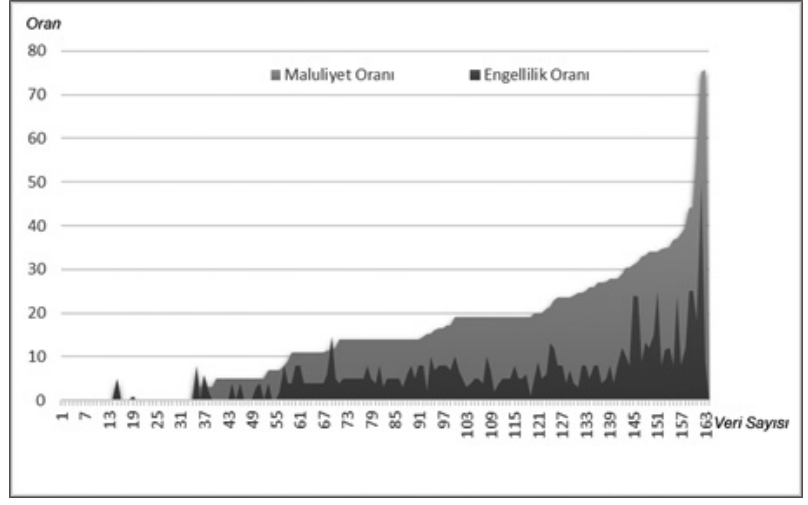

Grafik 2. Verilerin meslekte kazanma gücü kaybı oranı ve özürlülük oranı karşılaştırması

\section{Tartışma}

Çalışmamızdaki olguların yaş ortalamaları meslekte kazanma gücü kaybı oranı ya da özürlülük oranı için diğer merkezlere başvuran olgularla uyumludur $(13,14)$. Yaş ortalamaları açısından bakıldığında ortalamanın 35 ila 40 yaşlarında olması ve aktif çalışma dönemlerinde olmaları özellikle meslekte kazanma gücü kaybı yönünden oldukça önemli sonuçlara yol açmaktadır. Cinsiyet açısından bakıldığında ise erkek olgu yoğunluğunun fazla oluşu adli vakalardaki genel kaideyi bozmamaktadır (10, 11, 12).

Travma türleri incelendiğinde; motosiklet kazalarının daha önce yapılan çalışmaların aksine öne çıkması ve özellikle genç erkeklerde anlamlı düzeyde farklı çıkmasının nedeni, motosikletin gençler tarafından özellikle son zamanlarda sayıları artan ve evlere servisin yapıldığ yerlerinde kullanılmaya başlanması ve hobi amaçlı olarak kullanılması, bunun dışında çalışmamızda tek taraflı kırıkları tercih etmemizin etkisi de olabilir $(3,10,13,14,15)$.

Travma sonucu meydana gelen ekstremite kırıkları değerlendirildiğinde; en sık kırık saptanan ilk üç kemik olan tibia, femur, tibia+fibula kırıklarının anlamlı olarak yüksek çıkması benzer çalışmalarla uyumlu bulunmuş olup trafik kazalarında kırıkların sıklıkla alt ekstremitede yoğunlaştığı, üst ekstremite kırıklarının da ikinci planda olduğu görülmüştür. Kömürcü ve arkadaşlarının yaptığ1 motosiklet kazalarına bağlı kas iskelet sistemi yaralan- 
malarına ait 189 olgunun bulunduğu çalışmada en s1k femur 37 (\%27.41), tibia 26 (\%19.26), el ve el bileği 13 (\%9.63) kırığı bulunmuştur (3). Literatürde ekstremite kırıklarının sıklık sırası değişmekle beraber kas iskelet sistemi yaralanmaları sonucu yaralanan vücut alanları bu konuda yapılan araştırmalardaki sonuçlarla uyumlu bulunmuştur (16).

Çalışmamızda intramedüller çivi veya plak-vida ameliyatı olanların alçı-atel tedavisi uygulananlara göre özürlülük ve meslekte kazanma gücü kaybı oranlarının anlamlı olarak yüksek olduğu sonucuna varıldı. Bu sonucun tedavinin etkinliğinden ziyade yaralanmanın ağılık derecesiyle alakalı olduğunu, alçı-atel tedavisi uygulanan olgulardaki düşük meslekte kazanma gücü oranı ve özürlülük oranlarının bu tedavi yönteminin daha hafif yaralanmalarda uygulanmasından kaynaklandığını düşünmekteyiz. Özellikle cerrahi tedavilerin kırığın tipine göre seçilmesi ve konservatif tedavilerin genellikle nondeplase ve komplike olmayan ve de eklem bölgesi içermeyen kırıklarda tercih edilmesi nedeniyle bulgularımız şaşırtıcı değildir (4-8).

Eroğlu I'nin 78 olguyla yaptığı uzmanlık tezinde takdir uygulanan arızaların D cetveli ve Özür Oranları Cetvelinden aldıkları oranlar arasında üst ekstremite arızaları dışında anlamlı farklılık saptanmadığı, ayrıca D cetveline göre yapılan 67 değerlendirmede takdir uygulanan ve uygulanmayan pelvis ve alt ekstremite, baş, yüz, omurga, iç organ ve kulak arızalarının D cetveli ve Özür Oranları Cetvelinden aldıkları oranlar karşılaştırıldığında anlamlı farklılık saptanmadığı, üst ekstremite arızaları D cetveli ve Özür Oranları Cetveline göre değerlendirildiğinde D cetveline göre yapılan değerlendirmede üst ekstremite arızalarının tamamında takdir uygulandığı ve elde edilen oranlar arasında istatistiksel olarak anlamlı farklılık bulunduğu belirtilmektedir (17). Bizim çalışmamızda ise tek taraflı ekstremite kırıkları sonucu meydana gelen sekeller ilgili cetvellerden hesaplanarak özürlülük ve meslekte kazanma gücü kaybı oranı karşılaştırıldığında aynı sekelin özürlülük ve meslekte kazanma gücü kaybı oranı arasında anlamlı olarak fark olduğu saptandı. Ayrıca çalışmamızda özürlülük ve meslekte kazanma gücü kaybı oranı arasında pozitif yönde güçlü bir ilişki olduğu saptanmıştır. Bu farklılıkların nedeni her iki yönetmelikteki aynı arızaların karşılığındaki değerlendirme farkı olmasının büyük rolü vardır. Ayrıca "Özürlülük Ölçütü, Sınıflandırması ve Özürlülere Verilecek Sağlık Kurulu Raporları Hakkındaki Yönetmelikte" ortopedik değerlendirmeler diğer yönetmeliktekine göre büyük oranda farklıdır. Özellikle alt ekstremite değerlendirmelerinde; birinde eklem hareket kısitlılıkları ve eklem sertlikleri göz önünde bulundurulurken "Özürlülük
Ölçütü, Sınıflandırması ve Özürlülere Verilecek Sağlık Kurulu Raporları Hakkındaki Yönetmelikte" ise yürüme ile ilgili subjektif ve tecrübe isteyen bir değerlendirme öne çıkmaktadır. Ayrıca benzer değerlendirmelerde de yani üst ekstremite ve alt ekstremitede kısıtlılık açısından yapılan değerlendirmelerde “Özürlülük Ölçütü, Sınıflandırması ve Özürlülere Verilecek Sağlık Kurulu Raporları Hakkındaki Yönetmelikte" oranların diğer yönetmeliğe nazaran daha düşük olduğunu görmekteyiz. Dolayısıyla meydana gelen bu fark ciddi tazminat farklarına da neden olmaktadır.

\section{Sonuc}

Çalışmamızda elde edilen veriler ışığında tazminat davası sebebiyle başvuran hastaların demografik profili literatürle uyumlu olmasına karşın, özellikle artan trafik yoğunluğu, motosiklet kullanımının ciddi derecede arttığını ve motosiklet kullanımı gerektiren işlerin ve hobi olarak daha sık kullanımının bu artışa katkıda bulunduğunu görmekteyiz. Bu nedenle motosiklet kullanan genç erkek popülasyonuna yönelik eğitimlerin arttırılması ve özellikle kask ve diğer koruyucu kıyafetlerin yanında alt ekstremiteye yönelik olarak kullanılan koruyucu kıyafetlerin özendirilmesi ve yasal olarak desteklenmesi gerektiğini düşünmekteyiz.

Kırıklar açısından baktığımızda alt ve üst ekstremite kırıklarına yönelik konservatif ve cerrahi tedavi tekniklerinin giderek gelişmesine rağmen, özellikle aktif iş yaşamında olan genç erişkinlerde daha sık görülmesi ciddi iş gücü kaybına ve daha sık sigorta şirketlerine olmak üzere açılan davalarda ciddi tazminat ödemeleri yapılmasına sebep olmaktadır.

Trafik kazalarının tazminat açısından değerlendirmesinde yapılan değişiklikler sonucunda 01.06.2015 yılından sonra meydana gelen kazalarda meslekte kazanma gücü kaybı oranı yerine özürlülük oranının kullanılmas1 ve bu oran hesaplanırken meslek ve yaş değerlendirilmesinin yapılmaması mevcut oranların düşmesine ve hak kayıplarına neden olacağı açıkça görülmektedir. $\mathrm{Bu}$ nedenle buna yönelik mağduriyetin ortadan kaldırılması için daha objektif değerlendirmeleri içeren ve yaş ile mesleğin de hesaba katıldığı ayrı bir yönetmelik oluşturmaya yönelik adımlar atılması gerektiği kanaatindeyiz. Özellikle ortopedik değerlendirmeler ile ilgili baktığımızda; 01.06.2015 tarihinden sonra kullanılan "Özürlülük Ölçütü, Sınıflandırması ve Özürlülere Verilecek Sağlık Kurulu Raporları Hakkındaki Yönetmelik” ortopedik değerlendirmeler ile 20.02.2019 tarihli ve 30692 sayılı Resmî Gazetede yayınlanan "Erişkinler İçin Engellilik Değerlendirmesi Hakkında Yönetmelikteki" ortopedik 
değerlendirmeler arasında fazla bir yenilik de yapılmamıştır. Yapılan yenilikler minör düzeyde kalmıştır. Örneğin yeni yönetmelikte küçük değişiklikler yapılmış olup üst ve alt ekstremite ile ilgili nörolojik ve vasküler nedenli fonksiyonel değerlendirmeler bu başlık altında toplanmıştır.

Ayrıca 20.02.2019 tarihli ve 30692 sayılı Resmi Gazetede yayınlanan "Erişkinler İçin Engellilik Değerlendirmesi Hakkında Yönetmelikte"; trafik kazası sonucunda meydana gelen sekellerin değerlendirilmesinde; "kurulda birden fazla uzmanlık dalını ilgilendiren engel durumlarının tespitinde kurul, kurul başkanı ve aşağıdaki branşlardaki uzman hekimler olmak üzere en az yedi daimi üyeden oluşur: İç Hastalıkları Uzmanı, Göz Hastalıkları Uzmanı, Kulak Burun Boğaz Hastalıkları Uzmanı, Genel Cerrahi Uzmanı, Nöroloji Uzmanı, Ruh Sağlığı ve Hastalıkları Uzmanının yanı sıra kurul başkanının teklifi ve başhekimin onayı ile diğer branşlardan erişkinin hastalık durumuna göre kurula ilgili branş uzmanı davet edilebilir. Bu hâlde ilgili branş uzmanı geçici kurul üyesi olarak raporu imzalar. Rapor vermeye yetkili sağllk kurum ve kuruluşlarında, Fizik Tedavi ve Rehabilitasyon Uzmanı bulunması hâlinde, bu uzmanın kurulda yer alması zorunludur. Bulunmaması durumunda varsa Ortopedi ve Travmatoloji Uzmanı kurula katılı" ibaresinin yer alması diğer bir handikap olarak değerlendirilebilir. Çünkü söz konusu branşların yanı sıra bu kurullarda Adli Travmatoloji ve bilirkişilikte uzman olan Adli Tip Uzmanlarının yer alması gerek yönetmeliğin kullanımı gerekse arızaların değerlendirilmesinde ortaya çıkan yorum farklarının engellenmesi açısından adli tıbbi değerlendirme için gereklidir. Bunun dışında 20.02.2019 tarihli ve 30692 sayılı Resmî Gazetede yayınlanan "Çocuklar İçin Özel Gereksinim Değerlendirmesi Hakkında Yönetmelikte" de Ek 3 'te yer alan puanlama tablosuna bakıldığında $\% 20$ ve \%99 arasında özel gereksinim ile ilgili hastayı değerlendiren kurula $\% 9$ gibi ciddi tazminat farklarına sebep olabilecek taktir hakkı tanıan "mevzuat ve uyum arasında kullanılan tablo verilmiştir. Bu durum her iki yönetmeliğin kullanımında mevcut kurullardaki klinisyenler de göz önüne alındığında özellikle adli olgular ve tazminat ile ilgili raporlarda oldukça temkinli davranan klinisyenlerin yapmaktan çekinecekleri bir iş haline gelmesine yol açacağından, tüm dünyada bu raporların Ortopedi ve Travmatoloji, Fizik Tedavi ve Rehabilitasyon gibi alanlarında uzman hekimler, Adli Travmatoloji konusunda eğitimli hekimler tarafından düzenlendiği göz önüne alındığında bu tür değerlendirmeler için ülkemizde oluşturulan bu kurullara Adli Tıp Uzmanı hekimlerin mutlaka eklenmesi ya da bu tür raporların bu kişiler tarafından verilmesinin gerekliliğini ortaya koymaktadır.

\section{Kaynaklar}

1. Karayolu Trafik Kaza İstatistikleri, 2017, TÜİK. http:// www.tuik.gov.tr/PreHaberBultenleri.do?id=27668 (erişim tarihi: 04.03.2019).

2. Polat O. Adli Travmatolojide Trafik Kazalarına Genel Bak1ş. Adli Tıp Bülteni. 1996;1(1):18-25.

3. Kömürcü E, Arık K, Hatay Gölge U, Nusran G, Kurt T. Aksaray İlinde Meydana Gelen Motosiklet Kazalarına Bağlı Kas İskelet Sistemi Yaralanmaları, Türkiye Acil Tıp Dergisi - Tr J Emerg Med 2013;13(1):19-24, doi: https://doi.org/10. 5505/1304.7361.2013.15013

4. Ateş Y, Ömeroğlu H, Uçar HD, Korkusuz Z. Tibia cisim k1rıklarında farklı tedavi metodlarının karşılaştırılması, Acta Orthop Traumatol Turc 28, 90-93, 1994.

5. Karaismailoğlu TN, Gülman B, Şen S, Çıray M. Erişkin humerus cisim kırıklarında tedavi, Omü Tıp Dergisi, 9, 2, 1992.

6. Demirtaş AM, Kalem M. Erişkinlerde ön kol kırıkları, TOTBİD (Türk Ortopedi ve Travmatoloji Birliği Derneği) Derg, 7 (1-2):35-39,2008.

7. Ada S, Bal E. El Kırıklarının Tedavisi, TOTBID (Türk Ortopedi ve Travmatoloji Birliği Derneği) Derg, 3 (1-2),2004

8. Keklikçi K, Çilli F, Pehlivan Ö, Kuşkucu M. Femur Boyun Kırıkları, OTBID (Türk Ortopedi ve Travmatoloji Birliği Derneği) Derg, 8 (1):1-6, 2009

9. Türktaş U., Yalçın N., Erişkin Tibia Cisim Kırıklarında Kilitli İntrameduller Çivi Uygulamaları, Van Tıp Dergisi: 18 (1):20-26, 2011

10. Hekimoğlu ve ark. Maluliyet Oranlarının Yaş ve Cinsiyet İle İlişkisinin Değerlendirilmesi, Van Tıp Derg 24(3): 173181, 2017, DOI: https://doi.org/10.5505/vtd.2017.53244

11. Kır MZ, Yavuz MS, Uluçay T, Zeyfeoğlu Y, Kahraman İ, Tatar G. Özürlü Sağlık Kurulunda Değerlendirilen Trafik Kazası Olgular1, CBU-SBED, 2015, 2(4):106-109

12. Kaya A, Meral O, Erdoğan N, Aktaş E. Maluliyet Raporlarının Düzenlenmesi Anabilim Dalımıza Başvuran Olgu Özellikleri İle. Adli Tıp Bülteni. 2015;20(3):144-151. DOI: https://doi.org/10.17986/blm.2015314259

13. Eşiyok B, Korkusuz İ. Yaşlılarda Travmaya Bağlı Maluliyet. Turkish Journal of Geriatrics, 2006; 9(4):213-217.

14. Meuleners LB, Lee AH, Haworth C. Road environment, crash type and hospitalisation of bicyclists and motorcyclists presented to emergency departments in Western Australia. Accid Anal and Prev 2007;39:1222-5.

15. Sataloğlu N, Aydın B, Turla A. Bisiklet ve Motorsiklet Kazası Sonucu Yaralanma ve Ölümler. Adli Tıp Bülteni. 2010;15(1):13-20. DOI: https://doi.org/10.17986/ blm.2010151701

16. Alıcıoğlu B, Yalnız E, Eskin D, Yılmaz B. Motosiklet kazalarına bağlı yaralanmalar, Acta Orthop Traumatol Turc 2008;42(2):106-111

17. Eroğlu İ. 2015-2016" yılları arasında adli tıp anabilim dalında "çalışma gücü ve meslekte kazanma gücü kaybı oranı tespit işlemleri yönetmeliği cetvelleri”" kullanılarak düzenlenmiş “iş gücü kaybı (maluliyet)" konulu rapor sonuçlarının "özürlülük ölçütü, sınıflandırması ve özürlülere verilecek sağlık kurulu raporları hakkında yönetmeliğindeki özür oranları cetveli” ile karşılaştırılması. [Uzmanlık Tezi] Süleyman Demirel Üniversitesi Tıp Fakültesi Adli Tıp Anabilim Dal1. Isparta, 2017. $91 \mathrm{~s}$. 